Research Article

\title{
Impact of educational session on knowledge and attitude towards antimicrobial prescribing and awareness about antimicrobial resistance among undergraduate medical, dental and nursing students: a comparative study
}

\author{
Tushar Jayant Tamboli ${ }^{1}$ *, H.P. Pundarikaksha ${ }^{1}$, Manjunatha Ramaiah ${ }^{2}$, \\ Kirtan Anandbhai Bhatt ${ }^{1}$, Shruthi Rajendra Prasad ${ }^{3}$
}

${ }^{1}$ Department of Pharmacology, Kempegowda Institute of Medical Sciences, Bangalore, Karnataka, India

${ }^{2}$ Regional Medical Advisor, Novo Nordisk, Chennai, Tamilnadu, India ${ }^{3}$ Medical Safety Advisor, Quintiles, Bangalore, Karnataka, India

Received: 29 May 2016

Accepted: 01 July 2016

*Correspondence to:

Dr. Tushar Jayant Tamboli, Email: tushkimbbs@gmail.com

Copyright: (C) the author(s), publisher and licensee Medip Academy. This is an openaccess article distributed under the terms of the Creative Commons Attribution NonCommercial License, which permits unrestricted noncommercial use, distribution, and reproduction in any medium, provided the original work is properly cited.

\begin{abstract}
Background: Educational interventions targeting undergraduate medical students provide a great opportunity to strengthen the efforts to promote rational prescribing and to decrease antimicrobial resistance. A better understanding of knowledge and beliefs of students about issues of antimicrobial use and resistance, and analysing the improvement after educational session, can assist in devising an effectively tailored educational intervention. The objective of this study was to comparison of knowledge and attitude about antimicrobial prescribing and awareness about resistance amongst medical, dental and nursing undergraduates before and after an educational session on antimicrobial use and resistance.
\end{abstract}

Methods: A pre-validated questionnaire on knowledge and attitude about antimicrobial use and resistance was distributed to second year medical (80), dental (61) and nursing (37) students before and after an educational session. Results obtained were compared within and between the groups by using paired t-test and one-way ANOVA respectively. P-value $<0.05$ was considered to be statistically significant.

Results: All groups showed statistically significant improvement in knowledge and attitude scores following the session on antimicrobial use and resistance $(\mathrm{P}<0.001)$. Post-session attitude scores of medical students were better than that of dental and was statistically significant $(\mathrm{P}=0.006)$. The pre-session evaluation showed that medical students had better knowledge and attitude about antimicrobial use and resistance as compared to dental $(\mathrm{P}<0.001)$ and nursing students $(\mathrm{P}<0.001)$

Conclusions: Significant improvement in attitude and basic knowledge following an educational session about antimicrobial prescribing and awareness about antimicrobial resistance in undergraduate students suggest establishment of special course on rational prescription of antimicrobials in undergraduate curriculum.

Keywords: Antimicrobial prescribing, Antimicrobial resistance, Educational session

\section{INTRODUCTION}

Extensive use of antimicrobial agents (AMAs) adding to an increased selection pressure and poor infection control policies favouring the spread of resistant microorganisms are the two main contributing factors for antimicrobial resistance (AMR) especially in developing countries. ${ }^{1}$
There is an increased risk of acquiring infection with resistant microorganisms in patients receiving AMAs which can adversely affect the treatment outcome with increased morbidity and mortality, treatment costs, disease spread, and duration of illness. ${ }^{2}$ One of the major causes of deaths in developing countries are community acquired infections, particularly respiratory and 
gastrointestinal, and some of the most common factors contributing towards AMR include patient demands, doctors personal preference, lack of culture and sensitivity results leading to uncertain diagnosis, sales of antimicrobials without prescription, and pharmaceutical promotional tactics. ${ }^{2,3}$

$20 \%$ and $50 \%$ of antimicrobial used are either unnecessary or inappropriate, and the major reasons for misuse of antimicrobials are lack of established prescribing criteria for physicians, absence of control in drug dispensation, and incorrect patient usage. ${ }^{4,5}$ Changes in prescribing behaviour can reduce the antimicrobial use which will decrease the incidence of AMR. Therefore, knowledge about the reasons for AM prescription is needed, which can be obtained by means of KAP-surveys (knowledge, attitudes and practice surveys). ${ }^{1}$ Prescribers have a key role in prevention of antimicrobial resistance, by their safe and rational prescribing, and also by promoting patient awareness and knowledge and imparting health education to the community regarding safe medication practices concerning antimicrobials. ${ }^{6} \mathrm{~A}$ study has described the inability of the prescribing physicians in creating awareness and providing adequate education to the patients regarding antimicrobial usage which may be due to the inadequate training during their undergraduate and postgraduate years, reducing their ability to undertake these tasks confidently. ${ }^{6,7}$ Medical students will in a few years enter the global health work force and become one of the most important contributors in the medical field, which necessitates interventions targeting them and provide a great opportunity to strengthen the efforts to decrease antimicrobial resistance. By educating the next generation of physicians, before they develop bad habits of irrational prescribing of antimicrobials, overprescribing can be decreased. $^{8}$ A study in the UK showed that by educating undergraduates and graduates at education level on antimicrobial prescribing and resistance, quality of future antimicrobial prescribing can improve. ${ }^{9}$

It has been greatly emphasized that adequate training should also be provided to the undergraduate dental and nursing students along with the medical students regarding the proper prescribing and dispensing of antimicrobials in order to promote the judicious use of antimicrobials. $^{6,10-12}$ A better understanding of knowledge and beliefs of students about issues of antimicrobial use and resistance and analysing the improvement after educational session can assist us in devising an effectively tailored educational intervention. ${ }^{6}$

Hence, this study was undertaken amongst $2^{\text {nd }}$ year medical, dental and nursing undergraduate students, in order to assess their knowledge and attitude concerning antimicrobial resistance, and to compare the knowledge, attitude and practice of antimicrobial prescribing and awareness about antimicrobial resistance amongst medical, dental and nursing undergraduates before and after an educational session.
The objective of this study was to compare the knowledge and attitude about antimicrobial prescribing, and awareness about antimicrobial resistance amongst medical, dental and nursing undergraduates before and after an educational session on antimicrobial use and resistance.

\section{METHODS}

This was a questionnaire based study conducted in 178 second-year undergraduate students (medical-80, dental61, nursing-37), with prior IEC approval at KIMS, Bangalore, Karnataka, India. The study was carried out in $2^{\text {nd }}$ year medical, dental and nursing students obtaining prior informed consent, with study duration of 1 month. A modified questionnaire based on previous studies was used as a tool and was validated. ${ }^{6,13}$ The questionnaire consisted of 9 questions of knowledge of antimicrobial prescribing and awareness about antimicrobial resistance, 7 questions about attitude about antimicrobial prescribing and awareness about antimicrobial resistance and questions about possible causes of antimicrobial resistance. The questionnaire was divided in 4 parts: part 1 of the questionnaire included demographic data of the students: age, gender, address. Part 2 of the questionnaire assessed the participant's knowledge by using a set of true and false questions and the results were tabulated as percentages. Part 3 of the questionnaire assessed the participant's attitude about antimicrobial prescribing and awareness about antimicrobial resistance and the results were tabulated as percentages. Part 4 of the questionnaire assessed the most common causes of antimicrobial resistance according to the students. The performance was assessed by scores $(0=$ wrong response and $1=$ correct response), and the total score was calculated. The participants were made to undergo a training session of 2 hours regarding the empirical and rational use of antimicrobials, preventing/avoiding antimicrobial resistance, organized and executed by the investigator in collaboration with the departmental faculty. After the training session, the participants were asked again to answer the same questionnaire administered to them and the response was documented. The results were compared before and after the educational session both within the group and between the groups. Results were analysed using paired t-test and one-way ANOVA $(\mathrm{P}<0.05$ was considered significant). Descriptive statistics were used wherever necessary.

\section{RESULTS}

Table 1: Demographic characteristics of the subjects.

\begin{tabular}{|lllll|}
\hline Faculty & Total & Age & \multicolumn{2}{c|}{ Gender } \\
& & (in years) & male & female \\
\hline Medical & 80 & $20.53 \pm 0.56$ & 37 & 43 \\
\hline dental & 61 & $19.86 \pm 0.48$ & 13 & 48 \\
\hline Nursing & 37 & $19.42 \pm 0.76$ & 02 & 35 \\
\hline
\end{tabular}

*Age in years is expressed as mean \pm SD. 
Table 1 show the demographic data of students who participated in the study. Majority of the participants were females. The mean age of participants was 20.53 years in medical, 19.86 years in dental and 19.42 years in nursing.

Table 2: Knowledge about antimicrobial prescribing and awareness about antimicrobial resistance in medical, dental and nursing students.

\begin{tabular}{|c|c|c|c|}
\hline Questions (correct response) & $\begin{array}{l}\text { Medical } \\
(\mathrm{N}=\mathbf{8 0}) \mathrm{n}(\%)\end{array}$ & $\begin{array}{l}\text { Dental } \\
(\mathrm{N}=61) \mathrm{n}(\%)\end{array}$ & $\begin{array}{l}\text { Nursing } \\
(\mathbf{N}=37) \text { n }(\%)\end{array}$ \\
\hline $\begin{array}{l}\text { Are there bacteria in human body which are good for our health? } \\
\text { (Yes) }\end{array}$ & $80(100)$ & $58(95.08)$ & $26(70.27)$ \\
\hline $\begin{array}{l}\text { Can antimicrobials be used to cure infections caused by bacteria? } \\
\text { (Yes) }\end{array}$ & $79(98.75)$ & $61(100)$ & $35(94.59)$ \\
\hline $\begin{array}{l}\text { Can antimicrobials be used to cure infections caused by viruses? } \\
\text { (No) }\end{array}$ & $69(86.25)$ & $17(27.86)$ & $21(56.75)$ \\
\hline Bacteria are germs that cause common cold and flu? (No) & $70(87.5)$ & $33(54.09)$ & $16(43.24)$ \\
\hline $\begin{array}{l}\text { Do you think the use of antimicrobials will speed up the recovery } \\
\text { of cold, cough and other diseases? (No) }\end{array}$ & $31(38.75)$ & $21(34.42)$ & $07(18.91)$ \\
\hline $\begin{array}{l}\text { Antimicrobials are obtainable without interference of a doctor at } \\
\text { drug stores or pharmacies? (i.e. antimicrobials are over-the-counter } \\
\text { drugs) (No) }\end{array}$ & $30(37.5)$ & $28(45.9)$ & $23(62.16)$ \\
\hline Have you heard of antimicrobial resistance in bacteria? (Yes) & $79(98.75)$ & $53(86.88)$ & $34(91.89)$ \\
\hline $\begin{array}{l}\text { Do you think frequent use of antimicrobials will decrease the } \\
\text { treatment when using the antimicrobial again? (Yes) }\end{array}$ & $52(65)$ & $38(62.29)$ & $14(37.83)$ \\
\hline Have you heard of drug susceptibility testing of bacteria? (Yes) & $75(93.75)$ & $35(57.37)$ & $13(35.13)$ \\
\hline
\end{tabular}

$\mathrm{N}=$ total number of students of particular stream, $\mathrm{n}=$ Number of students of the particular stream with correct response.

Table 3: Attitude towards antimicrobial prescribing and antimicrobial resistance in medical, dental and nursing students.

\begin{tabular}{|c|c|c|c|}
\hline Questions (correct response) & $\begin{array}{l}\text { Medical } \\
(\mathrm{N}=80) \text { n }(\%)\end{array}$ & $\begin{array}{l}\text { Dental } \\
(\mathrm{N}=61) \text { n }(\%)\end{array}$ & $\begin{array}{l}\text { Nursing } \\
(\mathbf{N}=37) \mathbf{n}(\%)\end{array}$ \\
\hline Do you think there is abuse of the current antimicrobials? (Yes) & $78(97.5)$ & $46(75.4)$ & $28(75.67)$ \\
\hline Is bacterial antimicrobial resistance a problem in India? (Yes) & $80(100)$ & $40(65.57)$ & $24(64.86)$ \\
\hline $\begin{array}{l}\text { Is abuse of antimicrobials the main cause of bacterial resistance? } \\
\text { (Yes) }\end{array}$ & $74(92.5)$ & $25(40.98)$ & $25(67.56)$ \\
\hline $\begin{array}{l}\text { Can antimicrobial resistance affect you and your family's health? } \\
\text { (Yes) }\end{array}$ & $78(97.5)$ & $41(67.21)$ & $18(48.64)$ \\
\hline $\begin{array}{l}\text { Do you think it is necessary to get more information about } \\
\text { antimicrobials? (Yes) }\end{array}$ & $80(100)$ & $59(96.72)$ & $33(89.18)$ \\
\hline $\begin{array}{l}\text { Is it necessary to establish the course "Rational use of } \\
\text { antimicrobials" at the university level? (Yes) }\end{array}$ & $74(92.5)$ & $53(86.88)$ & $22(59.45)$ \\
\hline $\begin{array}{l}\text { Is it necessary to carry out a large-scale "antimicrobials } \\
\text { campaign" promotion? (Yes) }\end{array}$ & $66(77.5)$ & $48(78.68)$ & $18(48.64)$ \\
\hline
\end{tabular}

$\mathrm{N}=$ Total number of students of particular stream, $\mathrm{n}=$ Number of students of the particular stream with correct response.

Table 2 summarizes the response of students on various questions about knowledge about antimicrobial prescribing and resistance. Poor knowledge was seen in nursing and dental students regarding use of antimicrobials in viral infection and majority of the students from all groups $(66.86 \%)$ felt that antimicrobials will hasten the recovery of cold, cough and other diseases. Most of the students $(54.50 \%)$ also felt that antimicrobials are over the counter drugs. However, majority of students had heard about antimicrobial resistance (93.28\%), and drug susceptibility testing of bacteria $(69.1 \%)$.

Table 3 summarizes the response of students on various questions about attitude related to antimicrobial prescribing and resistance. Majority of the students $(85.39 \%)$ felt that there is abuse of antimicrobials in our 
country, and is a major cause for bacterial resistance in India. Most of them felt a need to receive more information about antimicrobials and a necessity to establish course on rational use of antimicrobials.

Table 4 documents the rating by undergraduate students of the possible causes of antimicrobial resistance according to their importance as felt by the students. Use of antimicrobials with a broader than necessary spectrum was the most common cause of antimicrobial resistance according to the dental students $(27.86 \%)$, while lack of restrictions on antimicrobial usage was the most common cause according to medical $(30 \%)$ and nursing $(37.83 \%)$ students.

Table 4: Rating by the undergraduate students of the possible causes of antimicrobial resistance according to their importance.

\begin{tabular}{|llll|}
\hline Causes of antimicrobial resistance & Medical $(\mathbf{N}=80) \mathbf{n}(\%)$ & Dental $(\mathbf{N}=61) \mathbf{n}(\%)$ & Nursing $(\mathbf{N}=37) \mathbf{n}(\%)$ \\
\hline $\begin{array}{l}\text { Use of antimicrobials for self-limited non } \\
\text { bacterial infections }\end{array}$ & $18(22.5 \%)$ & $15(24.59 \%)$ & $10(27.02 \%)$ \\
\hline $\begin{array}{l}\text { Use of antimicrobials with a broader than } \\
\text { necessary spectrum }\end{array}$ & $13(16.25 \%)$ & $11(18.03 \%)$ & $04(10.81 \%)$ \\
\hline $\begin{array}{l}\text { Use of antimicrobials for shorter than } \\
\text { standard duration }\end{array}$ & $08(10 \%)$ & $09(14.75 \%)$ & $09(24.32 \%)$ \\
\hline Poor infection control measures & $03(3.75 \%)$ & $10(16.39 \%)$ & $08(21.62 \%)$ \\
\hline $\begin{array}{l}\text { Use of antimicrobials for self-limited } \\
\text { bacterial infections }\end{array}$ & $13(16.25 \%)$ & $05(8.19 \%)$ & $06(16.21 \%)$ \\
\hline $\begin{array}{l}\text { Empirical antimicrobial therapy (best } \\
\text { guess therapy) }\end{array}$ & $00(0 \%)$ & $04(6.55 \%)$ & $07(18.91 \%)$ \\
\hline $\begin{array}{l}\text { Mutational and evolutionary changes in } \\
\text { the micro organism }\end{array}$ & $01(1.25 \%)$ & $13(21.31 \%)$ & $14(37.83 \%)$ \\
\hline Lack of restrictions on antimicrobial usage & $24(30 \%)$ & $09(14.75 \%)$ & $06(16.21 \%)$ \\
\hline $\begin{array}{l}\text { Excessive antimicrobial use in livestock } \\
\text { (animals reared for food) }\end{array}$ & $10(12.5 \%)$ & $08(13.11 \%)$ & $04(10.81 \%)$ \\
\hline $\begin{array}{l}\text { Use of antimicrobials for longer than } \\
\text { standard duration }\end{array}$ & $02(2.5 \%)$ & $17 \%)$ & $04)$ \\
\hline
\end{tabular}

$\mathrm{N}=$ Total number of students of particular stream, $\mathrm{n}=$ Number of students of the particular stream giving a particular response.

Table 5: Comparison of mean pre-session and post-session scores in the study groups about knowledge and attitude about antimicrobial prescribing and resistance, before and after an educational session using paired t-test.

\begin{tabular}{|c|c|c|c|c|c|}
\hline Students & Parameters & $\begin{array}{l}\text { Pre-session scores } \\
(\text { mean } \pm \text { SD })\end{array}$ & $\begin{array}{l}\text { Post-session scores } \\
(\text { mean } \pm \text { SD })\end{array}$ & $t$ & $P$-value \\
\hline \multirow{2}{*}{ Medical } & Knowledge (9) & $7.06 \pm 1.118$ & $8.93 \pm 0.265$ & -14.555 & $<0.001$ \\
\hline & Attitude (7) & $6.63 \pm 0.603$ & $7 \pm 0.00$ & -5.560 & $<0.001$ \\
\hline \multirow{2}{*}{ Dental } & Knowledge (9) & $5.64 \pm 1.426$ & $8.87 \pm 0.340$ & -16.351 & $<0.001$ \\
\hline & Attitude (7) & $5.11 \pm 1.305$ & $6.89 \pm 0.321$ & -10.464 & $<0.001$ \\
\hline \multirow{2}{*}{ Nursing } & Knowledge (9) & $5.11 \pm 1.542$ & $8.86 \pm 0.347$ & -14.081 & $<0.001$ \\
\hline & Attitude (7) & $4.54 \pm 1.574$ & $6.95 \pm 0.229$ & -9.011 & $<0.001$ \\
\hline
\end{tabular}

P-value* indicates statistical significance $(<0.05)$.

Table 5 shows the comparison between the pre-session and post-session scores for knowledge and attitude about antimicrobial prescribing and awareness about antimicrobial resistance within the groups. There was a statistically significant improvement in the post-session scores of both the parameters in all the three groups.

Figure 1 presents the inter-group comparison of mean knowledge scores (9) before and after the educational session using one-way ANOVA. The pre-session evaluation showed that out of the total 9 questions, medical students scored the highest mean score of 7.06, followed by dental (5.64) and nursing students (5.11). On pre-session inter group analysis, medical students had better knowledge about antimicrobial prescribing and resistance as compared to dental $(\mathrm{P}<0.001)$ and nursing students $(\mathrm{P}<0.001)$. No significant difference was noted between dental and nursing students. After the session, there was a statistically significant improvement in the mean scores in all the groups with medical students 
scoring the highest mean score of 8.93 followed by dental (8.87) and nursing students (8.86). In the post-session analysis, there was no significant difference between the groups.

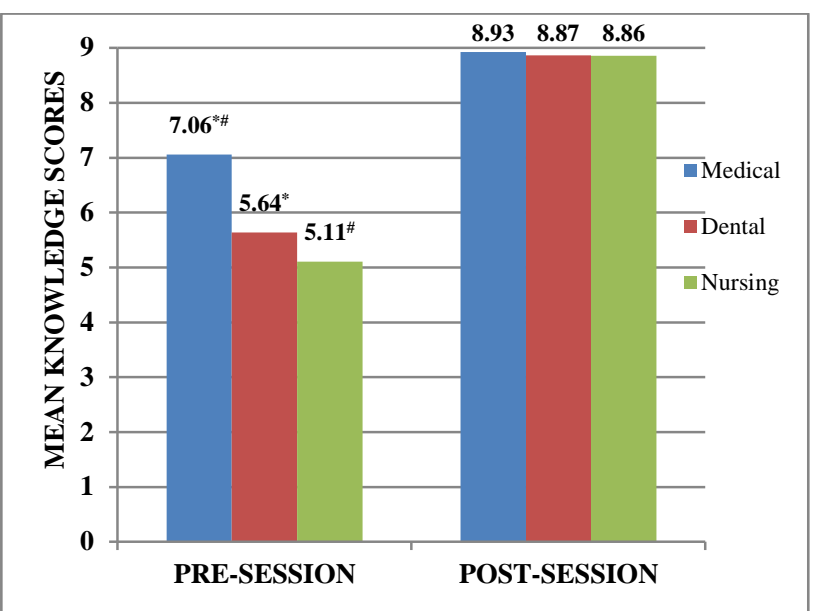

Values are expressed as mean scores. $* \mathrm{P}<0.001, \# \mathrm{P}<0.001$.

Figure 1: Inter-group comparison of knowledge scores (9) before and after the educational session using oneway ANOVA.

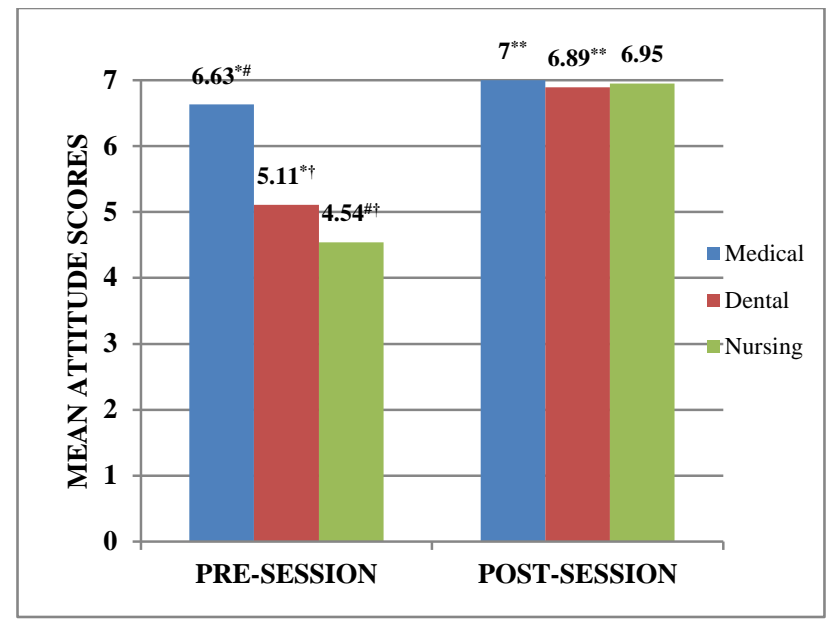

Mean attitude scores are plotted. $* \mathrm{P}<0.001, \# \mathrm{P}<0.001, \dagger \mathrm{P}=0.04$, $* * \mathrm{P}=0.006$.

Figure 2: Inter-group comparison of attitude scores (7) before and after the educational session using oneway ANOVA.

Figure 2 demonstrates the inter-group comparison of mean attitude scores (7) before and after the educational session using one-way ANOVA. The pre-session evaluation showed that out of the total 7 questions, medical students scored the highest mean score of 6.63, followed by dental (5.11) and nursing students (4.54). On pre-session inter group analysis, showed that medical students had better attitude about antimicrobial prescribing and resistance as compared to dental $(\mathrm{P}<0.001)$ and nursing students $(\mathrm{P}<0.001)$, and dental students achieved better attitude scores as compared to nursing students $(\mathrm{P}=0.04)$. After the session, there was a statistically significant improvement in the mean scores in all the groups with medical students scoring the highest mean score of 7 followed by nursing (6.95) and dental students (6.89). In the post-session analysis, medical students achieved better attitude scores than the dental students $(\mathrm{P}=0.006)$, while no significant difference was noted between dental and nursing students.

\section{DISCUSSION}

The clinical effectiveness of antimicrobials depends on their correct use on patients by physicians. ${ }^{14}$ There was a significant improvement in the knowledge and attitude scores in all the groups when compared with their respective pre-session scores. This shows that there is scope for improvement in the knowledge by inculcating course on rational use of AMAs in the curriculum of medical and paramedical courses, who will prescribe/dispense/administer antimicrobials in future.

The pre-session evaluation showed that medical students had better knowledge about antimicrobial use and resistance as compared to dental and nursing students. It might be because medical students get more knowledge through literature and clinical practice than other students. The results were similar to other studies. ${ }^{13,15}$ The response to attitude on antimicrobials was also much better in medical students as compared to other branches. The results were similar to previous studies. ${ }^{13,15}$ In postsession analysis, there was no significant difference in the knowledge scores in between the groups. However, medical students achieved better attitude scores as compared to dental students.

Pre-session evaluation showed poor knowledge about the use of antimicrobials in viral illness in dental and nursing students, with $72.14 \%$ of the dental students and $43.25 \%$ of nursing students believing that antimicrobials should be prescribed for viral illness. Similar results were seen in previous studies. ${ }^{11,13,16,17}$ A significant percentage of dental (54.09\%) and nursing (43.24\%) students also believed that bacteria are germs that cause common cold and flu. Findings were similar to previous studies. ${ }^{6,13}$ Such wrong beliefs lead to inappropriately high rates of antimicrobial consumption, which can result in corresponding increase in antimicrobial resistance, as seen in other study. ${ }^{14}$ However, majority of medical students $(86.25 \%)$ believed that antimicrobials should not be used for viral illness, similar to the observation in previous studies. ${ }^{13,14}$

Majority of the students from all the groups were aware of the nationwide problem of antimicrobial resistance, and they felt that there is misuse of antimicrobials in our country, which is a major cause for bacterial resistance. The findings were similar to previous studies. ${ }^{10,14,18}$ Majority of the students from all the groups felt the necessity for more education on antimicrobials, and a need to establish the course on rational use of antimicrobials in the curriculum. The findings were 
consistent with previous studies. ${ }^{4,10,13,18}$ Use of antimicrobials with a broader than necessary spectrum was the most common cause of antimicrobial resistance according to the dental students, while lack of restrictions on antimicrobial usage was the most common cause according to medical and nursing students. Similar results were observed in previous studies. ${ }^{6,18}$

The limitations of the study was conducted only in $2^{\text {nd }}$ year students in a single institution with a small sample size. Only a single session was conducted with immediate assessment.

\section{CONCLUSION}

The pre-session evaluation showed that medical students had better knowledge and attitude about antimicrobial prescribing and resistance as compared to dental and nursing students, and there was statistically significant improvement in knowledge and attitude scores following an educational session on antimicrobial prescribing and awareness about antimicrobial resistance in all the study groups.

\section{ACKNOWLEDGEMENTS}

We convey our sincere thanks to the students who voluntarily participated in this study.

Funding: No funding sources Conflict of interest: None declared

Ethical approval: The study was approved by the Institutional Ethics Committee

\section{REFERENCES}

1. Garcia C, Llamocca LP, García K, Jiménez A, Samalvides F, Gotuzzo E, et al. Knowledge, attitudes and practice survey about antimicrobial resistance and prescribing among physicians in a hospital setting in Lima, Peru. BMC Clinical Pharmacology. 2011;11:11-8.

2. Okeke IN, Laxminarayan R, Bhutta ZA, Duse AG, Jenkins $\mathrm{P}, \mathrm{O}$ 'Brien TF, et al. Antimicrobial resistance in developing countries. Part I: recent trends and current status. Lancet Infect Dis. 2005;5:481-93.

3. Jamshed SQ, Elkalmi R, Rajiah K, Al-Shami AK, Shamsudin SH, Siddiqui MJ, et al. Understanding of antibiotic use and resistance among final-year pharmacy and medical students: a pilot study. J Infect Dev Ctries. 2014;8(6):780-5.

4. Pulcini C, Williams F, Molinari N, Davey $\mathrm{P}$, Nathwani D. Junior doctors' knowledge and perceptions of antibiotic resistance and prescribing: a survey in France and Scotland. Clin Microbiol Infect. 2011;17:80-7.

5. De Sa Del Fiol F, Barberato-Filho S, Lopes LC, de Cassia Bergamaschi C, Boscariol R. Assessment of Brazilian pharmacists' knowledge about antimicrobial resistance. J Infect Dev Ctries. 2015;9(3):239-43.

6. Khan AK, Banu G, Reshma KK. Antibiotic resistance and usage-a survey on the knowledge, attitude, perceptions and practices among the medical students of a southern Indian teaching hospital. Journal of Clinical and Diagnostic Research. 2013;7(8):1613-6.

7. Chen C, Chen YM, Hwang KL, Lin SJ, Yang CC, Tsay RW, et al. Behaviour, attitudes and knowledge about antibiotic usage among residents of Changhua, Taiwan. J Microbiol Immunol Infect. 2005;38:53-9.

8. Kallberg C. Medical students' views on the current and future antibiotic resistance situation. Sahlgrenska Academy, University of Gothenburg. Available at http://www.reactgroup.org/uploads/react/resources/2 60/Medical\%20students\%E2\%80\%99\%20views\%20 on\%20the \%20current $\% 20$ and $\% 20$ future\%20antibioti c\%20resistance\%20situation.en.319.pdf. Accessed on 10 November 2015.

9. Simpson SA, Wood F, Butler CC. General practitioners' perceptions of antimicrobial resistance: a qualitative study. J Antimicrob Chemother. 2007;59:292-6.

10. Farhat S, Bhat MY, Rather ZM. A questionnaire based survey on antibiotic usage and resistance among second professional medical students in a tertiary care centre. Int $\mathbf{J}$ of Res In Pharmacology and Pharmacotherapeutics. 2015;4(3):314-9.

11. Gowri S, Mehta D, Kannan S. Antibiotic use in dentistry: a cross-sectional survey from a developing country. Journal of Orofacial Sciences. 2015;7(2):904.

12. Sharma K, Jain P, Sharma A. Knowledge, attitude and perception of medical and dental undergraduates about antimicrobial stewardship. Indian Journal of Pharmacology. 2015;47(6):676-9.

13. Huang Y, Gu J, Zhang M, Ren Z, Yang W, Chen Y, et al. Knowledge, attitude and practice of antibiotics: a questionnaire study among 2500 Chinese students. BMC Medical Education. 2013;13:163.

14. Mahajan M, Dudhgaonkar S, Deshmukh S. A questionnaire based survey on the knowledge, attitude and practises about antimicrobial resistance and usage among the second year MBBS students of a teaching tertiary care hospital in Central India. IJPR. 2014;4(4):175-9.

15. Ganesh M, Sridevi SA, Paul CM. Antibiotic use among medical and para medical students: knowledge, attitude and its practice in a tertiary health care centre in Chennai- a scientific insight. International Journal of Scientific Research. 2014;3(7):332-5.

16. Suaifan G, Shehadeh M, Darwish DA, Al-Ijel H, Yousef AM, Darwish RM. A cross-sectional study on knowledge, attitude and behavior related to antibiotic use and resistance among medical and non-medical university students in Jordan. Afr J Pharm Pharmacol. 2012;6(10):763-70. 
17. Scaioli G, Gualano MR, Gili R, Masucci S, Bert F, Siliquini R. Antibiotic use: a cross-sectional survey assessing the knowledge, attitudes and practices amongst students of a school of medicine in Italy. PLoS ONE. 2015;10(4):1-12.
18. Dyar OJ, Pulcini C, Howard P, Nathwani D. European medical students: a first multicentre study of knowledge, attitudes and perceptions of antibiotic prescribing and antibiotic resistance. J Antimicrob Chemother. 2014;69(3):842-6.

Cite this article as: Tamboli TJ, Pundarikaksha HP, Ramaiah M, Bhatt KA, Prasad SR. Impact of educational session on knowledge and attitude towards antimicrobial prescribing and awareness about antimicrobial resistance among undergraduate medical, dental and nursing students: a comparative study. Int J Basic Clin Pharmacol 2016;5:1544-50. 